\title{
Lazarus Rises: Storying the Self in the Migrant Fandom of David Bowie
}

\author{
Toija Cinque
}

Deakin University, Australia

toija.cinque@deakin.edu.au

\section{Sean Redmond}

Deakin University, Australia

s.redmond@deakin.edu.au

\begin{abstract}
In this article we focus upon the ways that "migrants" in Melbourne have used David Bowie to story and make sense of their arrival to Australia, often as refugees or as people looking for a better life. In relation to identity and belonging, some recent work on music fandom (Groene and Hettinger 2015; Lowe 2003), has imposed a meta-frame on the empirical method, substituting voices for a top-down analysis and interpretation. Our approach is to instead draw both upon auto-ethnography and to allow our fellow fans to "story" their own responses, in an attempt to get beneath the modes of feeling that music fandom ignites - situated within the narratives that people construct as they talk these stories. We argue that Bowie's alternative and outsider status resonates keenly with people who find themselves "strangers" in a new land.
\end{abstract}

KEYWORDS: David Bowie, popular music, stardom and celebrity, music fandom, media cultures, audience and reception studies

\section{Introduction}

The role of auto-ethnography in the study of music fandom has a very limited and side-lined history. While it is certainly true that fan voices have been used to 
explore how music idols have been identified with, and why they matter at the level of identity and belonging (Groene and Hettinger 2015; Lowe 2003), this work often imposes a meta-frame on the empirical method, substituting voices of fans for a top-down analysis and interpretation. Our approach then, is to draw both upon auto-ethnography and to allow our fellow fans to "story" their own responses in an attempt to get beneath the modes of feeling that music fandom ignites - situated, as it will be, within the narratives that people construct as they talk these stories. This approach draws upon Ruth Finnegan's sociological method (1997), and the affective turn within star and celebrity studies (see Redmond 2014) whereby writing oneself into identification and desire is centred and encouraged rather than marginalized:

The "storying the self" approach to empirical research draws on a] model of the self as "storied" and of culture as both moulded and moulding through the personal stories of individuals ... It extends the idea of "culture" and media beyond the organizational structures of, say, the culture industries, broadcasting or the published media, into the everyday modes in which we express and construct our lives in personal terms, telling our own stories. (Finnegan 1997: 69)

The emphasis on "writing the personal" (Probyn 2011) has also been central to the epistemological and political interventions of popular culture theorists and those interested in "hearing" the stories of the marginalized and politically disenfranchized. Connected to this approach is the recognition that researchers also have stories to share and in a way that democratizes the empirical process no one story is more important than the other - and through shared story telling, experiential equivalences and "clusters" emerge. Through storying the self we find out about how people directly experience their own, often marginalized, subject positions.

Our figure to story will be David Bowie, as part of a larger project that we are undertaking on this mercurial, seminal figure of pop and rock music. The project is built around how fans make sense and meaning of Bowie, and will be connected to such themes as identity politics, memory and memorabilia, nostalgia, difference, and belonging and desire. His recent death will now also be a key strand in the project's overall architecture. We will be examining the way that fans "story" their appreciation of David Bowie via fieldwork in five key sites/cities around the globe to which Bowie was closely connected. For this article, however, we focus specifically upon the ways that "migrants" in Melbourne use David Bowie to story and make sense of their immigrant status in Australia, often as first generation migrants coming to terms with their "difference". As our research has found, Bowie's alternative and outsider status resonates keenly with people who find themselves "strangers" in a new land. Lyrically, musically and in terms of star representation, Bowie becomes, then, the figure through which migrants navigate themselves through new cultural and social environments. Here we also find that migrant identity readily intersects with sexuality, gender, class and age concerns, something we pick up on and develop in the course of this article. 
We define celebrity fandom as involving two, sometimes interrelating, forms, one that is individualized and individually sanctioned; and one that takes place in fan communities, defined as "the shared social contexts within which fan reading and creative practices occur" (Jenkins 2006). Those celebrity fans who individualize their active participation also often share and partake in communities, involving themselves in both a "private" form of intimacy with the celebrity, and a "public" one, where the sharing of knowledge, readings, desires, and the creation of homages and transcodings of existing texts takes place. According to Henry Jenkins (2010: web source), fandom is a key facet of participatory culture, where:

Fandom refers to the social structures and cultural practices created by the most passionately engaged consumers of mass media properties; participatory culture refers more broadly to any kind of cultural production which starts at the grassroots level and which is open to broad participation.

The participatory culture that builds around celebrity fandom can be argued to be regenerative, affecting the production and reception of the figure, as fans creatively transcode their meaning, produce and transmit new ways of understanding the celebrity, and engage in new forms of collective interaction. As John Caughie (1984: 40) suggests:

The basis of most fan relationships is not an esthetic appreciation but a social relationship. Fans have attachments to unmet media figures that are analogous to and in many ways directly parallel to actual social relationships.

For a number of scholars there is an understanding that in certain productive circumstances, fandom affords an individual with a sense of empowerment, and that some musical experiences can be responsible for indescribable, unlocatable sensations. For example, Ken McLeod (2003: 338) has argued that music is of fundamental importance because it

creates an embodied but imaginary space that mediates our internal space (feelings, desires, dreams) with external space (the physical, experienced) ... Music takes us outside our bodies and place while simultaneously reminding us of our location and what it means to live there.

Such forms of material transcendence have also been termed encounters of "enchantment" (Redmond: 2014: 126; Bennett 2001: 5) whereby heightened musical connections can be seen to occur in the presence of the performer, or in their absence, as in the case of recorded music. As Duffett (2012: 5) argues, through a close analysis of the fandom of Elvis Presley, music and a certain star performer can provide a vehicle for power and intimacy whereby: "that intimate moment of affective engagement then gives fans a stock of energy that can get them through the trauma of illness, divorce, and bereavement". In Nick Stevenson's empirical study of David Bowie fandom, we find a similar sense of empowerment. For example, one fan, Guy, comments: 
People tend to go back to it [Bowie's music] when they're having problems, they deal with it by secluding themselves through Bowie and turning to him for, like a guide, inspiration... or just to cope... (Stevenson 2009: 84)

For this project we adopted the focus group method for these various reasons: we intended for it to be a participatory space, where participants could openly share their stories. However, our focus on migrant identity in relation to the fandom of David Bowie sets the discussion in a cultural and social context that has not been explored by other fan scholars, or through a story-framed empirical method. This pilot study is unique in both focus and method.

\section{Migrant method}

By way of background to this study, Australia until the 1950s had defined itself largely as a "new Britannia" emulating the "empire" in the southern hemisphere (Langer 2001). With post World War II immigration, however, the "mono-culture" of Australia changed toward an official notion of "multiculturalism" or multiethnicity (Jupp 1996). The terms "multiculturalism" or "multi-ethnicity" are now frequently referred to in policy documents as "cultural diversity". Moreover, the terms "multicultural" and "ethnic" become imprecise when they are only associated with people from Non-English Speaking Backgrounds (NESBs) because English speakers in Australia form various ethnic groups, for example, the English, Irish or Welsh, but so do the many Aboriginal communities. According to Gillard (2002), the term "multiculturalism" was first used in Australia under the Whitlamled Labor government (December 1972 - November 1975) as part of its policy for Australia to move beyond its "White Australia" heritage and beyond the assimilation policies which had governed the initial years of post war migration. The constitution of Australia's population was changing with migrants coming increasingly from non-English speaking nations such as Italy, Greece and Germany rather than from the English speaking countries of England, Scotland, Ireland and Wales as had occurred in the past. By 1976 the national census revealed that one in five persons in Australia was born overseas and at least another one in ten had parents who were born overseas (Ethnic Television Review Panel 1980: 10). The most recent 2011 Australian Bureau of Statistics (ABS) Census recorded data indicating that where initially most migrants were born in countries in North-West Europe, followed by a number born in Southern and Eastern Europe. The proportion of the overseas-born population originating from Europe has now been in decline in recent years, from 52 per cent in 2001 to 40 per cent in 2011 (ABS 2012). Moreover, recent arrival data reflects the increasing number of people born in Asian countries:

Recent arrivals accounted for $47 \%$ of the total Indian-born population in Australia and $35 \%$ of the total Chinese-born population. In contrast, only $11 \%$ of the total United Kingdom-born population were recent arrivals. (ABS 2012) 
Data reveals that Country of Birth groups, which increased the most between 2001 and 2011 were India (up 200,000 people), China (176,200) and New Zealand $(127,700)$. The largest decreases were seen in the birth countries of Italy (less 33,300 people), Greece $(16,500)$ and Poland $(9,400)$ according to the ABS (2012). Almost half (49 per cent) of longer-standing migrants to Australia and 67 per cent of recent arrivals spoke a language other than English at home. New migrants to Australia came from almost one hundred countries and, in one way, a multicultural society can be understood to be one which is based on mutual respect and recognition of difference, having a commitment to the core values of Australian democracy and a desire to maintain harmony in the wider community (Jakubowicz and Newell 1995: 130-131). An alternative argument posed by Rex (1996: 15), however, sees multiculturalism as the means by which society is organized so that ethnic groups are incorporated and dominated by others; where these ethnic groups would otherwise be separate societies not bound by the state.

For the purpose of this study, clarity around the term "migrant" is justified in due consideration of its complexity. We in no way want to create another work that might be seen to commodify "the other". On culture and cultures, and the notion of "otherness" the important work of Edward Said (1978) presented the argument that the (postcolonial) West writes about and describes a version of the East in order to dominate it. In the Australian context, Seneviratne (1992) has argued that the Special Broadcasting Service (SBS) - a media organisation established initially for new migrants to the country - pursued an elitist and mono-cultural outlook as demonstrated in news and current affairs programming and employment policies marked by cultural superiority. As a consequence, "serious viewers" or "cosmopolitans" (usually the well-educated in upper income brackets) are able to enjoy, indeed revel in, "ethnic" culture - but from a distance. This act, Hage (1995) claims, supports ideological domination within the nation.

What is not distinguished in the argument above, however, is that the term "cosmopolitan" can refer to a group which, in Australia, includes people from various ethnic backgrounds because they too are often with secure socioeconomic status having come to Australia for "the better life" and also curious about the activities and interests of other communities. Our intention with this paper is not to "revel in" a version of "ethnic fandom" and popular-music culture but to allow fans to story their own "becoming". In undertaking the primary research, our aim was to discover the important ways that participants use $(\mathrm{d})$ David Bowie to "story" and make sense of their identity within Australia's particular cultural and social circumstances. Our aim was to learn how the fans felt about the work of David Bowie and move toward a richer understanding of how they have negotiated their own identity amidst a contemporary Western media culture that largely marginalizes the "alternative".

As a pilot study, four Melbourne-based adult participants, who self-identified as recent migrants to Australia or from a post-war migrant family, and as fans of David Bowie both, formed the first Fan Reference Focus Group in Metropolitan Melbourne. Our findings here are based on this first focus group session.

Fan Reference Focus Group participants were recruited from the researchers' network of peers. This was to ensure that individuals had appropriate interest in the research topic and were willing to participate. The Fan Reference Focus Group included the researchers themselves who were active in the discussions 
that took place. The focus group was composed of two males and four females with a modal age of 40 years, and lasted for approximately one hour. Five of them are quoted here, each from a family with a different ethnic background: ID (Chinese), MP (Italian), AN (Greek), NN (Irish), AP (Greek-British). The participants were invited to respond to open questions and visual stimuli (laid out on the table) about David Bowie's music and the role it plays (has played) in their lives. Participants were also asked to bring a special piece of memorabilia that they were invited to speak about, but not compelled to discuss. All interviews were audio-recorded and transcribed.

The focus group was organized around questions designed to enable the participants to "story" their fandom in relation to migrant identity and identity politics more generally (given the way that subjectivity is always involved in intersectionality). The session began with asking each of these participants why "they were here today" and "what it was about David Bowie they so identified with?" The conversation then continued with specific framing around how Bowie helped them each navigate their migrant identity, with each participant drawing upon a memory, event, or series of events to story his impact upon their lives. During the session we played softly a compilation of Bowie's music, and introduced visual stimuli - colour photocopied images of David Bowie from various decades and periods - and asked our participants to choose one that they felt they most identified with and to talk through their choice. The participants were then asked to story their self-chosen piece of Bowie memorabilia, linking it to their own (migrant) identity. Finally, we asked participants about how Bowie's recent death impacted upon them, and why they felt he was such an important figure (for migrants).

We listened to the transcripts four times, and made notes on each occasion, looking for clusters of themes that repeated themselves and which were drawn upon by all respondents either directly or in terms of supportive commentary and affirmative gestures. We found that there were five clusters of articulating or intersecting stories in relation to migrant identity and we have structured our article accordingly. We note that migrant identity was understood or addressed not simply in terms of: (1) identity difference, (2) ethnicity or nationality; and (3) family or community, but how it connected to questions and notions of (4) gender and sexuality; and ultimately an overall sense of (5) "resurrection".

\section{The difference in me}

Subjectivity includes our sense of self. It involves conscious and unconscious thoughts and emotions which constitute our sense of "who we are" ... We experience our subjectivity in a social context where language and culture give meaning to our experience of ourselves and where we adopt an identity. (Woodward 1997: 39)

As Woodward notes directly above, we come to take up an identity position in situational and temporalized contexts, which involve conscious and unconscious processes, and yet which are actively enacted within language and culture. 
Identity is never fixed (Hall 1990) and is involved in a range of intersections including class, sexuality, gender, ethnicity, age, and nationality. Often identity "is most clearly defined by difference, that is by what it is not" (Woodward 1997: 2) and becomes of importance "whenever one is not sure of where one belongs [or] is not sure how to place oneself among the evident variety of behavioural styles and patterns" (Bauman 1996: 19).

For our focus group participants, the question of difference and not (quite) belonging was central, and centrally tied to their migrant status and the role that Bowie had in both mitigating their sense of ethnic and cultural "otherness" and providing an audio-visual arena in which they could validate their "alien" identity through song, lyric and performance. Bowie made "weird cool" (ID), and:

In Adelaide, as a little working-class migrant girl, I was on the outside to the Anglo private school thing, but also on the outside to my own Italian community... he spoke on the border, through ambiguity... and enabled me to cherish not fitting in. (MP)

The sense that migrant identity involved alienation and exclusion from white Australia, as well as providing a conformist and claustrophobic environment to grow up in, was an often-repeated position. Our participants were caught by and yet resisted a number of cultural binds, as: outsiders within outsider migrant families; outsiders within conformist and religious migrant families; or as outsiders to Anglo-Saxon, white embodiment. As AN revealed:

I was very against the Greek upbringing, I didn't have any Greek friends, it was really conservative and oppressive. I hated being dragged to these fucking Greek dances... Bowie, his music, was a way of opening up a different path for me which said creativity, I didn't want to be the same as everyone else...

Similarly, ID reflecting on his own perceived oriental features and sense of ethnic otherness, as a child at school, shared:

I already felt weird. I was already the "Chinese Kid" in a private primary school where everyone else was white... and yet there was no race I felt I belonged to, no race I identified with, I was expunged from other races, I was having weird sexual thoughts because of my abuse, and I was also escaping into the grotesque and there was Bowie who encapsulated all that.

In different ways, each of the participants made reference to being (like) matterout-of-place - their migrant status a signifier of mutancy, detritus, and dirt. The Italian community, for example, considered MP's father effeminate, and his own perceived border crossing resonated with Bowie's androgyny. The common word drawn upon was "alien" both in relation to their sense of self and to Bowie's star images. This alien otherness was felt to be a pejorative, a not-belonging, and also a lived experience to be embraced and championed. For AN, the alien became the comforting norm, and the everyday became their version of alien living. Bowie was the regenerative force that enabled the reversal of these normative 
binaries - he gave the participants a way of experiencing what idealized countercultural life could be. As Frith (1996: 123) writes:

But if musical identity is, then, always fantastic, idealizing not just oneself but also the social world one inhabits, it is, secondly, always also real, enacted in musical activities. Music making and music listening, that is to say, are bodily matters; involve what one might call social movements. In this respect, musical pleasure is not derived from fantasy - it is not mediated by dreams but is experienced directly: music gives us a real experience of what the ideal could be.

Ghassan Hage (1997) argues that migrant home building is an active and conscious process of re-settlement, centred on the production and consumption of food and associated design and cultural practices. This home building combines the cultures of origin with the new setting and is as much about making place as remembering the space that one came from. For our participants, the migrant home was a haven or a prison, and sometimes both, its duality comforting and confronting. For AN, her Greek parents supported her desire to resist conformity, the strictures of Greek culture, and so Bowie's music filled the house and was welcomed. Similarly for AP, her dad shared with her cultish figures, such as Bowie, and embraced the transgressions that he embodied. Their "home building" together involved horror film nights and music video binges, away from the traditional Greek community she/they were also connected to.

For ID, the home he remembers is his own private hell. Conforming and relatively strict, the space was also the site where he suffered sexual abuse. Bowie was played to both hide the fact that this was taking place and was also the music that allowed our participant to soar beyond its earthly terror:

There was this weirdness emerging in me that was actually imposed by external sexual forces and no form to discuss it... All my drawings became very creepy. I drew monsters, hairy beings and I drew a lot of aliens. Escaping to the aliens is exactly what Bowie did and was an escape past his abuse.

Bowie is very often considered to be an artist one escapes in and through. His music reaches towards the stars, is engaged in alternative universes and grotesque histories, and his own liminal and transgressive images, enable him to be written on and over. In terms of identity, he allowed our participants to both find alternative selves within and in opposition to migrant identity, and to rise above the damage they encountered within everyday life.

\section{Family matters}

Controversial social commentator and knight-errant, David Bowie, struck a chord with fans who were growing up and becoming dissatisfied with the prevailing established narratives. For those feeling isolated or oppressed or closed off from wider society, Bowie afforded a portal to possibilities unknown. Imaginings garnered from the screen and sounds of "the seductive" presented a desirable 
visual and sonic "other" world; a tapestry consisting of the alluring leitmotif of (post)modernity. Bowie was a vehicle for social influence (Cinque et al. 2015; Devereux et al. 2015) and a central means by which our focus group participants, as young teens growing up in Australia, observed and evaluated themselves. Moreover, in the bosom of family (variously understood and experienced), Bowie provided a means to "new" thinking at critical junctures, adding shape to their world-views. For AN:

Bowie was a way of processing all the other shit that was considered "norm" and that was oppressive around me. He became my way of putting stuff together and saying, "No! This is my world; this is the stuff I love and if that is 'grotesque', then so be-it!"

Many fans came to Bowie's work very early in their lives and the same was found to be true within the Fan Reference Focus Group. Bowie "reached out" to them shrewdly expressing "life-threatening ideas" (ID) - what it might mean to exist "outside" certain norms so that they came to an understanding of their particular distinctiveness being challenged by the (then?) dominant oppressive characterisations of gender, race and ethnicity (see Cross et al. 1983) that they were being faced with and where "Bowie made it OK" (ID). In parts of a society where they might not "fit", Bowie provided a space for them to inhabit, where they were content to be different and, even able to push back upon, the accepted culture around them. For MP:

I found Bowie at 12 or 13 and he was just the epitome of masculinity, the way I thought it was amazing, softly spoken and elegant - and here, I had also grown up with an uncle and a father who were similarly very different to the mainstream masculinity whether "the typical Italian" or "man's man" and for me, Bowie just spoke of ambiguity, of never knowing quite where you fit...

And when "seeds are planted the vine flourishes" (NN):

My parents emigrated from Ireland to the UK. I grew up initially in an Irish community; a catholic upbringing and quite a masculine one too. My Dad was a masculine man, not a "bruiser" in any way but quiet tough and I had this conservative, forceful upbringing. But for me, Bowie presented a figure beyond this sort of doctrine - a heavenly embodiment that I loved; I absolutely adored it. I didn't know at the time what it was, no idea, but the visceral connective response to Him I have kept all my life and it has steered me right in terms of my identity politics. (NN)

For the participants in the Fan Reference Focus Group, "Bowie-inspired" creative activities were also important to their emerging personal identity and to their wellbeing growing up in a family and/or community with which they were at times, at odds. While sometimes creativity can be negative when "darkly" motivated, for example, a torturer might be creative, but his/her creativity makes the world a worse place (see Gaut 2010), this facet was not found to be the case for participants in the Fan Reference Focus Group - indeed, participants' own 
creativity was personally valuable and instrumental. Noted above ID, as a young teen trying to "escape the grotesque" originating from his abuse, would draw aliens personified by Bowie as Ziggy Stardust and later Thomas Jerome Newton in The Man Who Fell to Earth. AN hand-sewed outfits inspired by the Diamond Dog, Halloween Jack, to enrage her family, especially her Greek father (who was disowned by her grandfather for not having a son) but that enthralled her sisters: ${ }^{1}$

I introduced my sisters to non-Greek music and I always went for the nontraditionally Greek things in music and fashion for example. I was very against the conservative and what I saw then as oppressive Greek upbringing...

Encouraging and fostering their creative spirit was understood by participants to be imperative to making sense of the world into which they had emerged or, in certain situations, the events forced upon them. For years growing up, MP crafted scrapbooks that she filled with images taken from popular music magazines of David Bowie:

I always felt like I was on the outside of the prevailing "Australian" culture and the Italian community both. My parents were anti-Catholic [Italians are commonly Catholic], not homophobic [Catholics are required, by biblical decree, to be homophobic] and they encouraged me to be a strong, strident, feminist, and; I was brought up differently to the "typical" nuclear family. I had two Mums and two Dads and I was brought up in a community. I had a gorgeous childhood - and then I went to school where I found that my life was considered "different" or "alien" and everyone else was living the socalled normal life. I was given labels like "neglected" and even "abused" which certainly was not the way I was brought up. Then at 12, I found David Bowie and I keenly remember a picture of him and Angie holding their son Zowie [MP finds the image in one of her scrapbooks]. And I thought "WOW", you could get families that were queer, that you could get families that don't live up to the norm and that this was another possibility.

What became apparent from participant comments was that in mainstream Australian society growing up, there was a seeming lack of overt "vision" for the ways in which people might live together harmoniously in the larger community while simultaneously being able to maintain, rather than dilute or lose, a strong sense of personal core values or identity. They did not, however, "give in" to this. For our participants, the use of key rituals, symbols and articles of belief allowed the then dominant cultural "norms" and/or practices to be resisted through drawing on an alternative, an "alien", so that they might question and explore the validity of the representation of lifestyles and values circulating at the time. As noted above, this was especially true for participants resisting the stereotypes of "family", "masculinity", and ethnic identity. For three of the participants, Bowie and his music afforded the cultural means of functioning effectively within their communities without feeling required to necessarily change their cultural allegiances or personal identities. For AD and MP, Bowie was an exploratory foray into new possibilities that moved in tandem or journeyed alongside other media of personal cultural significance rather than a retreat into a separated 
enclave. What is at stake then for the individual, is far more than supporting imprecise notions of unrestricted freedom of choice (to rock and popular music for instance) and the personal significance of such that lies therein. It concerns nothing less than how (and by whom) our dreams have been shaped.

\section{Grieving and healing}

There is no binary division to be made between what one says and what one does not say; we must try to determine the different ways of not saying such things, how those who can and those who cannot speak of them are distributed, which type of discourse is authorized, or which form of discretion is required in either case. There is not one but many silences, and they are an integral part of the strategies that underlie and permeate discourses. (Foucault 1990: 27)

The focus group method is in one sense "an incitement to discourse" (Foucault 1990: 17), organized to reveal the unspoken and to hear the silences that may remain. It is also an intervention into dominant discourse: a way of cracking open the capillaries of power nodes that circulate within everyday life. Celebrity culture is itself a discursive set of practices and processes involving confessional and gossip modes and modalities of communication. On the one hand, celebrity talk can be argued to reinforce the politics of the neo-liberal self and commodity culture. On the other, it can be argued to reveal inequalities and to challenge and counter normative behaviours and relations. Joshua Gamson sees celebrity gossip as involving an audience who reject the vertical (top-down) relationship between celebrity and consumer for a horizontal one involving a collective or shared evaluation of the famed figure under the spotlight (Gamson 1994: 177-178).

This was very much the case with our focus group - we found participants commenting on each others responses, offering words of encouragement and support, and using "echo" and reinforcement strategies to align their thinking and emotional investment. Words such as "icon", "alien", "elegant", "liminal", "boundary testing", and "border-crosser" were the most often used phrases, becoming a way of not only defining Bowie but also the shared investment in him. A collective and empowering "voice" emerged through this celebrity talk, one that in its sharing and hearing became a liberating tool of identification, and a form of progressive social cohesion. As previously discussed, migrant identity became a shared badge of resistance and transcendence. However, we not only found that in talking about Bowie - in sharing stories about how he impacted on the participants lives -he was a figure of "togetherness", but that in the "conversation" that took place, a healing processed emerged or was sought. As AP shared and AN responded:

AP: I was always a Bowie fan, like my first record was a David Bowie record, which my Dad bought for me when I was two. It was Let's Dance. And my Father passed away really recently, and he was a really big Bowie fan. A month ago, like a couple days before David Bowie. There was this weird thing that kind of happened with the mourning, that kind of fused to the point 
that the song was playing on the radio when he took his last breath was "Space Oddity"... weird sense of symmetry. And I thought my Dad would have really liked to come along...

AN: well he is here...

The sense that AP (and AN) re-materialize her father is a powerful one: we are party here to a ritual of grieving for both a loved one just lost and the shared subject of their affection and bonding. This is grieving and healing emerging in the same collective place - a place of new communion. AP is in part dealing with her grief by being here; a mechanism to deal with her Dad's death; it may ultimately work to support social cohesion. However, one may also see celebrity mourning as anti-structural and grieving as a carnal response to loss, and which open up mourners to doubt and confusion, rather than closure and cohesion. This can be seen as ritual of philosophical questioning and phenomenological experience.

Each of our participants used and uses Bowie at crisis or critical points in their lives. Bowie embodied a particularly transgressive and transcendent form of agency which was drawn upon to both garner support for the identity positions they were seeking to take up, or which offered a life affirming way of overcoming obstacles. Both AN and MP turned to Bowie to normalize and ratify their difference. MP revealed how as a child at school she struggled to talk in public and so used David Bowie to overcome her shyness and sense of strangeness and alienation from other children who would mark her out as different: "nah, you don't have a TV, we know your house ..." For MP, Bowie was a gateway to selfactualisation:

By the time I got to year 10 I still couldn't read out loud properly, couldn't do a presentation... The first time I ever did a presentation at school and managed to get through it was speaking about David Bowie. Such a strategy of diversion...

For ID, the question of grieving and healing was connected to the sexual abuse he suffered. Bowie was employed to hide the abuse but also became the voice, the melody, and the star image that allowed him to escape his abuse and abuser and overcome the deep traumas he faced. Nonetheless, for ID, Bowie was also the vehicle through which a darker side of self-realisation emerged:

[Holding up an image of Ziggy] I was in a psychiatric hospital, under observation, at the age of $17 \ldots$ thank God for David Bowie... personally speaking, the staring, insanity of the man...there is no other escape than madness... I spent my $18^{\text {th }}$ birthday in a psychiatric hospital.

For our participants, Bowie embodied a particularly transgressive and aggressive form of active agency, and self-empowerment, and yet was also a conduit of, and for, understanding suffering in the face of conformity and abuse:

AN: For me, it wasn't an escape... he became a way of processing all the other shit that was norm and oppressive around you... this is my world, the 
stuff I love, and if it means it is grotesque or horrific or alien or whatever the hell it was, then bring it on.

ID: That in itself became a kind of anchor.

One can argue that celebrity talk also works as a ritual of refusal to patriarchal norms, it offers one an "anchor" in a sea of complex, messy and unequal identity positions. Bowie acts as a nautilus for our participants - a sacred shape; perfect symmetry, ultimately capable of resurrection...

\section{Lazarus rises}

Now a man named Lazarus was sick ... "Our friend Lazarus has fallen asleep: but I am going... to wake him up" ... "Did I not tell you that if you believed, you would see the glory of God?" ... When he said this, Jesus called in a loud voice, "Lazarus, come out!" The dead man came out [of his tomb], his hands and feet wrapped with strips of linen, and a cloth around his face. (John 11: $1-44)$

The biblical story of The Death of Lazarus is about demonstrating publicly the wonder and power of God through the miracle of a dead man raised to life. In his video for the song Lazarus, created during a time in which he faced his own sickness (cancer), Bowie linked spiritual belief and death by depicting the metaphoric Lazarus bearing linen superposed around his head, perhaps pitting his faith upon his own spiritual and/or physical resurrection - or, is he in fact "The Exile Symbolised" on earth, with his covered eyes replaced by useless plastic buttons:

Son of man, you are living among a rebellious people. They have eyes to see but do not see and ears to hear but do not hear ... (Ezekiel 12:2)

If read in this way it is certainly an important religious statement, but it is also one with implications for being far from "salvation". We might present the provocation then that while seeking his own (our) "resurrection" through grappling with the esoteric, David Bowie acted concurrently to restore belief (life) to those suffering. One participant found accord in the Fan Reference Focus Group with this statement:

After everything that has happened I've been thinking a lot about how one person can have such an incredible impact on society in their life. I haven't been able to stop thinking about his death and because of that, his life and what he did. (AN)

While David Jones ("Jones" remained his legal surname) pursued a single dictum of exploring life's depths, he did so via the mercurial "Bowie" and associated characters, using different metaphors and metonyms at various times for different purposes (Cinque 2015). Throughout a rebellious biography involving resurrection moments, his rise and fall and rise again trajectory, acted as a contextual frame. As Redmond (2013: 377) argues: "his process of renewal means that Bowie 
constantly kills himself, an artistic suicide that allows for dramatic event moments to populate his music, and for a rebirth to emerge at the same time or shortly after he expires".

Reflecting upon his final expiration, when asked about the profound response to his death by people of all ages from around the globe, across popular culture and the avant-garde, AN commented:

On one hand it was the music and also how he performed as a musician - it really tested boundaries. So there was the message (for want of a better word) that was sent out that reached people that way (his music and his persona), but beyond that he was a cultural presence in cinema. He represented things in terms of identity in the media, testing sexuality, individuality, and creativity. So his impact crept out beyond the music - it wasn't like he was a great musician alone and that was the end of it. (AN)

For a number, his struggles suffered (depicted in his art) have help(ed) to create an existential understanding. An important study undertaken by Stever (2011) found that fandom could assist individuals to overcome difficult life events by reconnecting with their feelings allowing them to: "rejoin ... the social world" (2011: 3) after long periods of isolation - much like Lazarus emerging from the tomb, or Bowie "living on" in digital form, or the individual finding purpose anew:

My Dad came to Australia from Greece when he was 15 . He was actually helped to learn English by listening to Bowie albums because Bowie's diction was very, very good. He bought me my first Bowie album. So, he was a big Bowie fan. When he passed away and where the song playing on the radio was "Space Oddity", that was weird and a kind of symmetry that is always something that I have associated with Bowie. (AP)

I am so glad that we did this today [refers to the focus group]. After the news of His death it brought everyone together and has opened up another whole dimension for me. (AN)

One participant found great joy in great loss:

When Bowie died, my little ones who live overseas were coming to visit the very next day. Normally, I would be pretty morose and down about it, thinking about Bowie's death and what it meant and I would have locked myself away - but my children arrived at 8 o'clock the morning following his death - this let me forget not Bowie, but to live on. In a sense his death (a perfect death) came at a perfect time for me. (NN)

In a heightened ideological sense, with regular recurrence David Bowie's works have engaged with the suffering of everyday life while synchronously tendering renewal so that the pain of living unequally in the world might be evaluated, worked through and extinguished. Through his body, whether his intent or not, our own life events are explained or justified in ways that let us keep going. 


\section{Conclusion}

[I]dentities are never unified and, in late modern times, increasingly fragmented and fractured; never singular but multiply constructed across different, often intersecting and antagonistic, discourses, practices and positions. (Hall 1990: 223)

In this article we have demonstrated the way David Bowie has positively impacted upon migrant identity and how notions of the self and selfhood move across sheets of belonging and estrangement - themselves connected to age, gender, and sexuality. What we have seen emerging from these conversations from this ship of stories - is not only the way stardom impacts upon everyday life, but also the way identities are forged, shaped, and layered in dynamic points of intersectionality. As we have suggested, Bowie's own shape-shifting identity and liminality became the art, sound and the flesh that our participants were able to utilize to empower and enrich their own lives. Lazarus rose and continues to rise within them.

While in this article we have extracted clusters of themes, the talk that emerged, merged them - so that in one "story" from one participant, the themes of family/community; sexuality and gender; ethnicity and difference; and personal renewal or "resurrection" rose up together like the most beautiful song, like the most liberating sounding. That our participants deftly, unconsciously, wrapped the complexities of their lives around Bowie, tells us the way in which memory is enacted and active agency manifests in the world. Our work demonstrates the way fandom is decidedly private and continues to be beautifully communal. The talk of David Bowie not only allowed our participants to share how, why and when he mattered, revealing secrets and privacies rarely shared before, but in the telling and the hearing new understandings emerged - the participants saw their histories and herstories in a new light. Further, in the sharing, friendships emerged as stories aligned.

Of course, in a contemporary Australia, where certain "types" of migrant are left to waste away in detention camps, these stories of migrant belonging are particularly relevant and important. These ships welcome those who arrive on boats.

For the authors of this article, who are two life long David Bowie fans, the organisation of the focus group and its running, happened only a few weeks after his death. Our participation in the focus group, then, was not only to do with exercising our preferred research method, but also so that we could share our stories with everyone else - at a time of great sadness and some personal need. This article is for everyone who took part and it is for David Bowie. Lazarus Rises.

\section{Endnotes}

${ }^{1}$ Ziggy Stardust refers to David Bowie's 1972 album The Rise and Fall of Ziggy Stardust and the Spiders from Mars (RCA 1972). The Man Who Fell to Earth is a British science fiction drama film directed by Nicolas Roeg (1976) that featured David Bowie in the role 
of Thomas Jerome Newton. Diamond Dog refers to the concept album Diamond Dogs (RCA 1974), Halloween Jack is the album's lead character.

\section{Acknowledgements}

Warm thanks to Maria Pallotta-Chiarolli for planting the migrant seed.

\section{References}

\section{Bibliography}

ABS - Australian Bureau of Statistics 2012. Cultural Diversity in Australia.

Reflecting a Nation: Stories from the 2011 Census, catalogue no. 2071.0. http://www.abs.gov.au/ausstats/abs@.nsf/Lookup/2071.0main+features9020122013; Accessed: 18 February 2016.

Bauman, Z. 1996. From Pilgrim to Tourist - Or a Short History of Identity. In S. Hall and P. Du Gay Eds. Questions of Cultural Identity. London: Sage: 18-36.

Bennett, J. 2001. The Enchantment of Modern Life: Attachments, Crossings, and Ethics. Princeton: Princeton University Press.

Caughie, J. 1984. Imaginary Social Worlds: A Cultural Approach. Lincoln, NE: University of Nebraska Press.

Cinque, T. 2015. Semantic Shock: David Bowie! In T. Cinque and S. Redmond Eds. Enchanting David Bowie: Space/Time/Body/Memory. New York: Bloomsbury: 197-214.

Cinque, T. et al. 2015. Enchanting David Bowie: Space/Time/Body/Memory. New York: Bloomsbury.

Cross, T. et al. 1983. Face to Face, Day to Day Racism - CR. In G. Hull, P. B. Scott and B. Smith Eds. All the Women Are White, All The Blacks Are Men, But Some Of Us Are Brave. New York: The Feminist Press: 52-60.

Devereux, E. et al. Eds. 2015. David Bowie: Critical Perspectives. London: Routledge. Sixth edition.

Duffett, M. 2012. Applying Durkheim to Elvis. Transatlantica: Revue d'études Américaines 2: 1-7. https://transatlantica.revues.org/6095?lang=en; Accessed: 18 February 2016.

Ethnic Television Review Panel 1980. Programming for the Multicultural/Multilingual Television Service: Objectives and Policies. 6 February. Canberra: Australian Government Publishing Service.

Finnegan, R. 1997. Storying the Self: Personal Narratives and Identity. In H. Mackay Ed. Consumption and Everyday Life. London: Sage: 65-112.

Foucalt, M. 1990. The History of Sexuality: An Introduction. Vol. 1. New York: Vintage.

Frith, S. 1996. Music and Identity. In S. Hall. and P. Du Gay Eds. Questions of Cultural Identity. London: Sage: 108-127. 
Gamson, J. 1994. Claims to Fame: Celebrity in Contemporary America. Berkeley, CA: University of California Press.

Gaut, B. 2010. The Philosophy of Creativity. Philosophy Compass 5: 1034-1046. http://dx.doi.org/10.1111/j.1747-9991.2010.00351.x

Gillard, J. 2002. From "White Australia" to Whitlam: Migration and Multiculturalism in Australia. The Whitlam Government as Modernist Politics: 30 Years Later Conference. Canberra, 2-3 December 2002. https://www.hnet.org/announce/show.cgi?ID=131218; Accessed 18 February 2016.

Groene, S. L. and Hettinger, V. E. 2015. Are You "Fan" Enough? The Role of Identity in Media Fandoms. Psychology of Popular Media Culture 20 April 2015.

http://dx.doi.org/10.1037/ppm0000080

Hage, G. -

1995. The Limits of Anti-racist Sociology. UTS Review 1 (1): 14-21.

1997. At Home in the Entrails of the West: Multiculturalism, "Ethnic

Food" and Migrant Home-building. In H. Grace et al. Eds. Home/World:

Space, Community and Marginality in Sydney's West. London: Pluto Press: 99-153.

Hall, S. 1990. Cultural Identity and Diaspora. In J. Rutherford Ed. Identity: Community, Culture, Difference. London: Lawrence and Wishart: 222-237.

Jakubowicz, A. and Newell, K. 1995. Which World? Whose/Who's Home?:

Special Broadcasting in the Australian Communications Alphabet. In J. Craik, J. Baily and A. Moran Eds. Public Voices, Private Interests. Sydney: Allen \& Unwin: 130-146.

Jenkins, H. -

2006. When Fandom Goes Mainstream. Confessions of an Aca-Fan: The

Official Weblog of Henry Jenkins [blog].

http://henryjenkins.org/2006/11/when_fandom_goes_mainstream.html;

Accessed: 11 February 2011.

2010. Fandom, Participatory Culture, and Web 2.0 - A Syllabus,

Confessions of an Aca-Fan: The Official Weblog of Henry Jenkins [blog].

http://henryjenkins.org/2010/01/fandom_participatory_culture_a.html;

Accessed: 23 June 2011.

Jupp, J. 1996. Understanding Australian Multiculturalism. Canberra: Centre for Immigration and Multicultural Studies, Australian National University, Australian Government Publishing Service.

Langer, J. 2001. Media Democratisation in Australia: What Is It, Who's Got It, Where to Find It, How It Works (or Doesn't) - Part 2. Screen Education 26/27: 68-85.

Lowe, M. 2003. Colliding Feminisms: Britney Spears, "Tweens", and the Politics of Reception. Popular Music and Society 26 (2): 123-40.

http://dx.doi.org/10.1080/0300776032000095477

McLeod, K. 2003. Space Oddities: Aliens, Futurism and Meaning in Popular Music. Popular Music 22 (3): 337-55. http://dx.doi.org/10.1017/S0261143003003222

Probyn, E. 2011. Glass Selves: Emotions, Subjectivity, and the Research Process. In S. Gallagher Ed. The Oxford Handbook of the Self. Oxford: Oxford University Press: 1-10. 
Redmond, S. -

2013. Who Am I Now? Remembering the Enchanted Dogs of David

Bowie. Celebrity Studies 4 (3): 380-383.

http://dx.doi.org/10.1080/19392397.2013.831631

2014. Celebrity and the Media. London: Palgrave Macmillan.

Rex, J. 1996. Transnational Migrant Communities and Ethnic Minorities in Modern Multicultural Societies. In J. Rex. Ethnic Minorities in the Modern Nation State. London: Palgrave Macmillan: 96-113.

Said, E. 1978. Orientalism. New York: Pantheon Books.

Seneviratne, K. 1992. Multicultural Television: Going Beyond the Rhetoric. Media Information Australia 66 (1): 53-57. http://dx.doi.org/10.1177/1329878X9206600107

Stevenson, N. 2009. Talking to Bowie Fans: Masculinity, Ambivalence and Cultural Citizenship. European Journal of Cultural Studies 12 (1): 79-98. http://dx.doi.org/10.1177/1367549408098706

Stever, G. 2011. Celebrity Worship: Critiquing a Construct. Journal of Applied Social Psychology 41 (6): 1356-1370. http://dx.doi.org/10.1111/j.1559-1816.2011.00765.x

Woodward, K. 1997. Identity and Difference. London: Sage. Third edition.

\section{Discography}

David Bowie -

1972. The Rise and Fall of Ziggy Stardust and the Spiders from Mars. RCA, UK. 1974. Diamond Dogs. RCA, UK.

\section{Videography}

The Man Who Fell to Earth. 1976. Dir. Nicolas Roeg. British Lion Films.

\section{Interviews}

Fan Reference Focus Group. 2016. Conducted by Toija Cinque and Sean

Redmond. Deakin City Centre, Victoria, Australia, 4 February. 